\title{
EKSISTENSI DAN ADAPTASI \\ GRUP BAND THRASH METAL DAN ROCK DI NEGERI SYARIAT
}

Pardian Saputra

pardiansaputra18@gmail.com

UIN Ar-Raniry Banda Aceh

\begin{abstract}
Fatwa ulama no. 12 of 2013 on Art and Culture of Other Arts in Islamic Syariat in Banda Aceh, should the band with the rock music genre not be able to survive for long periods in 'Aceh. But in reality bands of music genre Thrash Metal and Rock is still survive and present with real in public space in Aceh. This study looks at how the development, existence, and adaptation of the bands Inverno and Cronic in Banda Aceh. The Cronic band was formed in 1999, while Inverno was formed in 2011 in Banda Aceh.From interviews with the band Cronic and personnel about the existence and adaptation Inverno they found that the factors that affect their existence among other ways, through their consistency in the work and the support they received from various parties.he daptations performed by Cronic and Inverno bands are through the adjustment of lyrics and the meaning of the song lyrics on the albums and singles that they release and make adjustments in terms of the outfit used when they concert as well as the theme song selection of each of their works
\end{abstract}




\section{PENDAHULUAN}

Sejarah peradaban hidup manusia tidak pernah bisa dipisahkan dari apa yang disebut dengan seni. Sepanjang peradaban hidup manusia, seni menjadi elemen pelengkap yang terus melekat dan mengikuti manusia itu sendiri. Jika seni diilustrasikan sebagai sebuah pohon, maka musik merupakan salah satu cabang dari pahon itu sendiri. Dengan kata lain jelas sudah bahwa musik merupakan bahagian yang tidak dapat dipisahkan dari seni dan manusia itu sendiri.

Salah satu dosen senior Fakultas Kesenian Institut Seni Indonesia Yogyakarta, lulusan dari Peabody Institute di Amerika yang bernama Suhastjarja, memberikan sebuah pengertian tentang musik, menurutnya musik merupakan ungkapan rasa indah manusia yang diekspresikan dalam bentuk suatu konsep pemikiran yang bulat, dalam wujud nada-nada atau bunyi lainnya yang di dalamnya mengandung ritme dan harmoni, serta mempunyai suatu bentuk dalam ruang waktu yang dikenal oleh diri sendiri dan manusia lain dalam lingkungan hidupnya, sehingga dapat dimengerti dan dinikmatinya.1 David Even juga membuat catatan sebuah definisi tentang musik. Dalam catatannya dia mengatakan bahwa musik merupakan ilmu pengetahuan dan seni tentang kombinasi ritmik dari nada-nada, baik vocal maupun instrumental, yang kemudian di dalamnya meliputi melodi dan harmoni sebagai ekspresi dari segala sesuatu yang ingin diungkapkan terutama aspek emosional.2

Musik memiliki daya tarik tersendiri karna apa yang terkandung di dalam lirik sebuah musik adalah ungkapan emosi dari individu-individu ataupun kelompok, maka hal ini menjadi poin penting kenapa perkembangan musik sangat mudah dan cepat diterima di dalam ruang publik. Musik mulai disukai oleh masyarakat di berbagai penjuru dunia. Berbagai macam genre musik memiliki ciri-ciri dan keunikan masing-masing di antaranya seperti Jazz, Blues, Jazz, Gospel, Funk, Techano, Rock, Metal dan lain-lain.

1 R.M Soedarsono, Pengantar Apresiasi Seni (Jakarta: Balai Pustaka, 1992), hal. 13.

2 Ibid., hal. 14. 
Aliran musik seperti Rock dan Metal merupakan beberapa aliran musik yang bernada keras, dilihat dari sudut pandang penyanyinya, sebagian besar vokalis metal bersuara growl, scream. Sedangkan penyanyi rock suaranya sedikit lebih melodis. Genre Metal di lihat dari segi distorsi gitarnya yang kuat dan tebal dan terkesan acak-acakan, kemudian tempo nada yang cepat disemua intrumen alat musiknya meskipun ada subgenre rock yang menggunakan nada slow seperti Slow Rock. Tema lagu genre Metal idientik dengan kegelapan, penyiksaan, dan darah. Sedangkan musik Rock protes kehidupan sosial, cinta, dan alam.3

Daerah Aceh juga merupakan salah satu wilayah yang masyarakatnya memiliki daya minat dan penikmat musik yang bisa dikatakan cukup banyak. Berbagai jenis genre musik berkembang di Aceh. Genre musik cadas juga berkembang di Aceh. Ada beberapa genre musik cadas yang berkembang di Aceh, di antaranya adalah genreRock dan Death/Thrash Metal. Aliran music ini secara perlahan mulai disukai oleh peminat dan penikmat musik di Aceh dan terus berkembang hingga dewasa ini.

Seiring berkembangnya genre musik cadas di daerah Aceh. Penikmat dan peminat musik cadas kemudian membentuk kelompok-kelompok yang lalu menciptakan lagu-lagu sendiri. Kelompok ini di sebut dengan grup band. Salah satu band cadas yang berkembang di Banda Aceh adalah Cronic dengan genre Thrash Metal dan Inverno dengan genre Rock. Dua band tersebut memiliki eksistensi tersendiri. Mereka masih tetap ada dan berkembang di daerah Aceh. Hal yang perlu diperhatikan bahwa keberadaan band yang memiliki eksistensi ini mampu beradaptasi dan musik ini bisa diterima di ruang publik, walaupun band tersebut berkecimbung di Aceh.

Syariat Islam di Aceh telah dibentuk berdasarkan Undang-Undang No. 44 Tahun 1999 tentang Penyelenggaraan Keistimewaan Propinsi Daerah Istimewa Aceh dan Undang-Undang No. 18 Tahun 2001 Tentang Otonomi Khusus Bagi Provinsi Daerah Istimewa Aceh dan Undang-Undang No. 11 Tahun 2006 Tentang Pemerintahan Aceh yang pada intinya menjelaskan

3 http://ipk.sinarharapan.co/ipk/read/150730149/bedanya-musik-metal-dan-musikrock, diakses pada 5 Juni 2017. 
bahwa kehidupan masyarakat Aceh yang religius, menjunjung tinggi adat, dan telah menempatkan ulama pada peran yang sangat terhormat dalam kehidupan bermasyarakat, berbangsa, dan bernegara. 4

Majelis Permusyawaratan Ulama Aceh (MPU) mengeluarkan fatwa No. 12 tahun 2013 mengenai Seni Budaya dan Hiburan lainnya dalam Syariat Islam yang ada di Aceh. Beberapa isi fatwa Majelis Permusyawaratan Ulama di Aceh terkait pergelaran seni dan musik di Aceh diantaranya syair dan nyanyian tidak bertentangan dengan syariat Islam, syair dan nyanyian tidak disertai dengan alat-alat musik yang haram seperti bass, piano, seruling, biola, gitar dan sejenisnya, syair dan nyanyian tidak berisi fitnah, caci maki, dusta, yang dapat membangkitkan nafsu syahwat, penyair dan penyanyi harus memenuhi kriteria busana muslim dan muslimah, penyair dan penyanyi tidak ditonton langsung oleh lawan jenis yang bukan muhrim, penonton tidak bercampur antara laki-laki dan peremuan, kegiatan bernyanyi dan bersyair dilakukan pada tempat dan waktu yang tidak mengganggu ibadah dan ketertiban umum, penyair dan penyanyi tidak melakukan gerakan-gerakan yang berlebihan atau dapat menimbulkan nafsu birahi.5

Dari apa yang telah dipaparkan di atas, seyogyanya komunitas genre musik cadas tidak bisa bertahan dalam jangka waktu yang lama di Aceh. Penerapan syariat Islam dan fatwa Majelis Permusyawaratan Ulama Aceh mengenai aturan pergelaran seni dan musik seperti yang sudah tertera jelas di paragraf sebelumnya menjadi tembok penghalang bagi eksistensi grup band tersebut. Namun dalam realitanya komunitas genre musik cadas masih tetap bertahan dan hadir dengan nyata dalam ruang-ruang publik di Aceh. Dengan demikian maka pokok penelitian ini adalah bagaimana eksistensi dan adaptasi komunitas musik cadas di Banda Aceh di tengah gemparnya syariat Islam.

4 Misran, “Pelaksanaan Syari'at Islam di Aceh”, Legitimasi, Vol. 1, No. 2, Januari-Juni 2012, hal. 154-155.

5 Untuk lebih lengkap baca: Fatwa Majelis Permusyawaratan Ulama Aceh Nomor 12 Tahun 2013 tentang Seni, Hiburan, dan Lainnya dalam Pandangan Syariat Islam, hal. 2-3. 


\section{METODE}

Metode penelitian yang dipilih dalam penelitian ini adalah deskriptif kualitatif. Tujuan dari penelitian kualitatif adalah untuk mengetahui apa yang terjadi di lingkungan di bawah pengamatan, seperti apapandangan partisipan yang berada di latar penelitian, dan seperti apa peristiwa atau aktifitas yang terjadi.6

\section{HASIL DAN PEMBAHASAN}

\section{Grup Band Cadas}

ThrashMetal adalah subgenre dari Heavy Metal. Ciri-ciri yang mudah untuk ditandai dari Genre Thrash Metal adalah tempo cepat dan agresif. Band yang menggunakan genre tersebut biasanya menggunakan ketukan perkusi yang cepat. LyricallyThrash Metal biasanya berurusan dengan isu-isu sosial. Empat band yang dianggap paling sukses dan berpengaruh adalah Metallica, Megadeth, Slayer dan Anthrax karena status mereka sebagai pelopor genre metal pada tahun 1980. Ciri-ciri lain dari Thrash Metal adalah riff gitar cepat degan gaya memetik agresif dan solo kilat cepat. Kemudian drum di lagu Thrash Metal fitur ekstensif menggunakan snaredrum dan bassdrum ganda.7

Rock adalah genre musik populer yang berakar dari Rhythm and Blues, musik Country dan lain sebagainya. Ciri khas musik genre Rock sering berkisar sekitar gitar lisrik atau gitar akustik, dan penggunaan back beat yang sangat kentara pada rhythm section dengan gitar bass dan drum, dan kibor seperti organ, piano. Disamping gitar atau kibor, saksafon dan harmonica bergaya Blues terkadang digunakan sebagai instrumen musik solo.8

Salah satu grup band dengan genre Thrash Metal yang berkembang di kota Banda Aceh adalah Cronic. Nama Cronic adalah singkatan yang

6 Emzir, Metode Penelitian Pendidikan Kuantitatif dan Kualitatif (Jakarta: PT. Raja Grafindo Persada, 2011), hal. 174.

7 https://gendown666.wordpress.com, diakses pada 15 juli 2017.

8 https://klinikmusik.wordpress.com/2014/10/19/genre-musik/, diakses pada 27 Juli 2017.

118 | pardian saputra 
diplesetkan dari kata kronik "Kreasi Orang Unik".9Band dengan genre musik Metal/Thrash Metal ini dibentuk pada awal tahun 1999 di tengah konflik berkepanjangan di Aceh. Pembentukan grup band ini dimotori oleh Suriadi Anuwar atau dikenal dengan sebutan Adi Kriting. Ia berperan sebagai vocal/gitar sekaligus satu-satunya personil tetap yang dimiliki oleh Cronic dari masa-kemasa. Adi Kriting lahir pada 19 mei 1977 di Banda Aceh.10 Sekarang ia menetap di Panterik kecamatan Lueng Bata. Pada masa awal terbentuknya band Cronic, mereka mulai berkecimpug serta bersaing dengan band-band atau pemusik yang ada ketika itu di Banda Aceh.11 Mereka juga mulai berkecimpung dalam mengikuti festival-festival besar dan bergengsi ketika itu seperti Walang Kadung pada tahun 1999 dan meraih juara satu, kemudian di tahun 2000 Cronic mengikuti festival Thrash Metal dengan tema 3 in 1dan lain-lain.12

Penelitian ini dilakukan di Studio Tujuh Tujuh kec. Lueng Bata Kota Banda Aceh. Untuk menuju ke Studio Tujuh Tujuh tempat pertama yang harus dituju adalah simpang Surabaya, yaitu simpang yang menghubungkan jalan menuju Batoh, Peuniti, dan Lueng Bata. Sekitar 500 meter masuk sebelah kiri kecamatan Lueng Bata dari simpang Surabaya akan bertemu dengan Bangunan P.T Sampoerna yaitu sebuah perusahaan rokok dengan merek Sampoerna cabang Banda Aceh. Kemudian menyeberang jalan dan berjalan sekitar 50 meter kearah Dapue Kupi, yaitu sebuah warkop yang menyediakan makanan dan segala jenis minuman.13

Warna cat yang digunakan pada bagunan Studio Tujuh Tujuh menggunakan warna hitam, putih dan orange. Pemilihan warna cat hitam, putih, dan orange untuk Studio Tujuh Tujuh adalah di karenakan warna tersebut dapat membuat bagunan itu terkesan kaya warna dan lebih tekesan

\footnotetext{
9 http://www.rhybuckrecords.com/2014/09/cronic-biography.html, diakses pada 16 Juli 2017.

10 Wawancara dengan Adi Kriting di Studio Tujuh Tujuh, Kecamatan Lueng Bata, pada 24 Juli 2017.

11 Wawancara dengan Adi Cronic di Studio Tujuh Tujuh, Kecamatan Lueng Bata, pada 16 Juli 2017.

12 https://www.facebook.com/cronicthrash, diakses pada 25 Juli 2017.

13 Wawancara dengan Adi Cronic di Studio Tujuh Tujuh pada 18 Juli 2017.
} 
netral. Dalam perjalanan mempersiapkan album di Banda Aceh, saat itu Cronic dipengaruhi oleh sejenis band-band cadas dari berbagai negara.

Grup band dari Eropa yang mempengaruhi musik Cronic antara lain seperti Kreator, band ini berasal dari Germany dan band ini memakai genre Thrash Metal. Band tersebut terbentuk pada1980.14 Kemudian Sepultura, merupakan sebuah grup band asal Brasil. Grup band Sepultura dibentuk pada 1984 dengan menggunakan genre Thrash Metal.15 Band lainnya adalah Napalm Death, grup band ini berasal dari Inggris. Grup band yang dibentuk pada tahun 1975 tersebut menggunakan genre Grindcore/Death Metal.16 Iron Maiden juga memiliki pengaruh besar dalam warna musik Cronic, grup band ini adalah grup yang kongsisten dengan genre Metal. Iron Maiden dibentuk pada tahun 1975 di Inggris.17 Within Temptation juga memberikan pengaruh yang sama, grup band ini aktif sejak tahun 1996. Grup asal Belanda ini menggunakan genre Symphonic Gothic Metal.18

Selain itu, grup band cadas ini juga dipengaruhi oleh grup musik asal Amerika antara lain seperti Dying Fetus, grup band ini terbentuk di Amerika. Grup dengan genre Death Metal ini aktif sejak tahun 1991.19 Kemudian Motorhead, grup ini menggunakan genre Rock and Roll. Motorhead dibentak pada tahun 1975 dan berasal dari Los Angeles.20 Grup lainnya adalah Slayer sebuah grup band yang lahir pada tahun 1981. Grup band asala California ini setia dengan genre Thrash Metal.21

Selain dipengaruhi oleh grup band asal Eropa dan Amerika, Cronic juga dipengaruhi oleh grup band lokal antara lain seperti Sucker Head, merupakan grup band asal Indonesia yang terbentuk di Jakarta pada tahun

14 https://www.facebook.com/KreatorOfficial, diakses pada 20 Juli 2017.

15 Wahyu Nugroho, "Sepultura Seharusnya Sudah Tamat", SINDONEWS.COM, 24 Juni 2015.

16 https://www.facebook.com/officialnapalmdeath, diakses pada 20 Juli 2017.

17 https://kandidatmusisi.wordpress.com/sejarah-perkembangan-iron-maiden, diakses pada 20 Juli 2017.

18 https://akatsuci.wordpress.com/sejarah-within-temptation, diakses pada 20 Juli 2017.

19 https://www.facebook.com/DyingFetus/, diakses pada 20 Juli 2017.

20 https://www.facebook.com/OfficialMotorhead, diakses pada 20 Juli 2017.

21 https://www.metal-archives.com/bands/Slayer/72, diakses pada 20 Juli 2017. 
1989.22 Kemudian Pas Band yang merupakan grup band asal Bandung. Band yang terbentuk pada 1990 ini menganut genre Rock, Hip Hop, Funk.23

Cronic merilis beberapa karya di antaranya berbicara terkait Aceh, motivasi, religi, dan moral. Karya-karya grup band Cronic yang membahas stuasi Aceh antara lain Album Dimensi Berganti tahun 2014 yang berbicara tentang sejarah Aceh dari masa ke masa. Kemudian Home yang berbicara tentang bagaimana seorang manusia mencoba untuk membatasi dirinya dan orang lain dengan menggunakan kata "Home Keueh" padahal manusia bisa lebih dari itu. namun yang membudaya didalam masyarakat adalah hal yang demikian. Karya lainnya adalah Kota Mati yang berbicara tentang bencana Tsunami yang pernah meluluh lantahkan sebahagian besar wilayah Aceh dan Banda Aceh pada tahun 2004. Single Pusaka RAYA ditahun 2017.24 Single ini berbicara tentang mimpi masyarakat Aceh dan keinginan masyarakat Aceh untuk masa Irwandi Yusuf agar dapat mengangkat martabat Aceh kembali sebagai mana sejarah Aceh yang dalam literature sejarah dikatakan perah Berjaya dalam segala hal hari ini. Setelah itu Titik, lirik lagu ini berkesinambungan dengan lagu Home yang hampir memiliki makna yang sama dengan kandungan lagu Home.

Karya-karya grup band Cronic yang membahas tentang moral antara lain Sang Ku Riang, Depresi Luar Kendali yang bercerita tentang keadaan anak manusia yang selalu saja depresi dalam berbagai hal yang dia lakukan dalam realita hidupnya. Kemudian Varandah of Mecca pada tahun 2008, Krisis Moral yang bercerita tentang bagaimana seorang manusia sedikit demi sedikit mulai mencoba keluar dari zona budaya tempat tinggalnya.Fatamorgana. Lagu ini berbicara tentang bagaimana lihainya manusia dalam menggukan akal mereka untuk mencari keuntungan dengan cara menipu, memberikan janji-janji palsu kepada sesama mereka. Kronis Phobia dan Tradisi Membodohi juga merupakan karya Cronic yang membahas tentang moral.

22 http://2013.hammersonic.com/line-up/sucker-head, diakses pada 20 Juli 2017.

23 http://www.izaybiografi.com/2016/01/biografi-pas-band.html, diakses pada 20 Juli 2017.

24 https://www.reverbnation.com/cronicthrash, diakses pada 21 Juli 2017. 
Karya-karya grup band Cronic yang membahas tentang religi antara lain Album Kundalini pada tahun 2015. Kundalini berbicara tentang bagaimana kesempurnaan yang diberikan oleh Allah SWT kepada manusia. Segala titik yang ada pada diri manusia seperti mata, telinga, dan sebagainya memiliki kekuatan yang besar ketika itu digunakan dengan baik dan bijaksana.25Dewasa ini Cronic dalam proses mempersiapkan karya-karya selanjutnya ditahun 2019 dengan nama Prasasti.26

Selain grup band Cronic, salah satu band dengan genre cadas yang juga berkembang hingga dewasa ini di Aceh adalah Inverno. Inverno dalam bahasa Italia artinya musim dingin, bukan Inferno yang artinya neraka. Pengucapan yang salah dari nama grup band dengan genre Rock/Modern Rock/Rock and Roll ini bisa membuat arti nama grupnya sangat berbeda.

Nama Inverno terinspirasi dari nama sebuah program acara televisi yang berjudul inferno ketika itu. Mulai dari situ Tebonk mempunyai keinginan untuk membuat nama band mereka dengan nama tersebut. Namun sebelum itu, Tebonk mengkonfirmasi terlebih dahulu kepada Tedy mengenai nama tersebut. Terjadi diskusi antara Tebonk dan Tedy yang berakhir pada kesimpulan pengambilan nama grup band mereka dengan nama Iverno bukan inferno.27

Band ini di nahkodai atau didirikan oleh Tedy Kelana dengan posisi di Inverno sebagai vocal atau yang sering dipanggil dengan sebutan nama Tedy dan Jefry Muntazier atau yang sering dipanggil dengan sebutan nama Tebonk dengan posisi di Inverno memegang alat musik bass.

Grup band dengan pendiri Teddy dan Tebonk, Sebelumnya mereka juga bergabung dalam satu bandRock, yaitu Bottom Lips pada tahun 2004 dan X-Box pada tahun 2005. Karna banyak dan lain hal mereka mengundurkan diri dari band tersebut dan membentuk band yang mengusung musik Hard Rock, Rock $n$ Roll yaitu grup band Inverno.

Grup band Inverno memiliki 4 personil antara lain Tedy Kelana lahir pada 21 maret 1980 di Jakarta, vokalis sekaligus pendiri grup band Inverno

25 Lihat lirik lagu Mugiwara di http://www.reverbnation.com/cronicthrust.

26 Wawancara dengan Adi Cronic, tanggal 14 Juli 2017.

27 Wawancara dengan Tebonk di HABA CAFFE pada 24 Juli 2017. 
ini mulai bermain musik sejak tahun 1995. Tedy sendiri pernah bermain dengan berbagai grup band seperti Bad Mood, Psycho, Nol Koma, Bottom Lips dan X-Box. Tedy beragama Islam. Pekerjaan Tedy selain bermain musik adalah Swasta \& Owner at Dream Organizer.

Jefri Muntazier / Tebonk di percaya sebagai bassis Inverno atau yang sering dipanggil dengan sebutan nama Tebonk lahir pada 7 oktober 1979 di Banda Aceh. Hobinya adalah mendengar musik dan makan siomay serta beragama Islam, alamat Labui. Bassis Inverno ini adalah operator recording. Selain itu, Tebonk juga banyak mengisi demo dan single lagu, baik milik band maupun penyanyi solo di Banda Aceh ditangani olehnya. Penggemar Flea, Rex, Bongky dan Duff mckagan ini sempat aktif di Paparazzi Band pada tahun 2000 ketika Tebonk masih di banku SMA, Bottom Lips pada tahun 1999 dan X-Box pada tahun 2003 s/d 2010.28

Teuku Furqan dengan posisi memegang gitar. Lahir di Banda Aceh, 30 mei. Teuku Furqan beragama Islam. Influence Furqan adalah Andy Timmons, Daren Houshoulder, dan Joe Satriani. Teuku Furqan beralamat di Jl. Angsa No. 2 Batoh, Banda Aceh.

Sebelum Teuku Furqan bergabung dengan Inverno, ia dulunya juga sudah pernah bergabung dengan grup band lain ketika dia masih masih menempuh jenjang pendidikan sekolah menengah atas dan mendapatkan project dengan bandmetal yaitu band Maggots.29 Personil yang paling muda yang Inverno miliki bernama Alif Maulana. Posisi drum dipegang oleh Alif. Dia lahir pada tanggal 12 agustus 2000 di Banda Aceh. Alif bergabung dan menjadi personil tetap Inverno pada tahun 2017.30

Grup band Inverno belum memiliki tempat khusus untuk berkumpul ataupun latihan. Ketika Inverno ingin konser atau diundang untuk tampil mengisi sebuah acara, mereka latihan di beberapa studio di kota Banda Aceh. Namun, studio rental yang biasa Inverno gunakan sebagai tempat untuk latihan adalah Studio 888 yang beralamat di jalan Bagau, kampung Keramat, kecamatan Kuta Alam.

28 http://musik.or.id/profile-inverno, diakses pada 22 Juli 2017.

29 Wawancara dengan Teuku Furqan Inverno pada 21 Juli 2017.

30 Wawancara dengan Alif Maulana Inverno pada 12 Agustus 2017. 
Dalam perjalanannya Inverno sering mengikuti live event antara lain seperti Konser Salam Lebaran, Artis: Cafein dan tiket, pada tahun 2005 di Banda Aceh. Ketika konser Salam Lebaran di adakan Inverno di undang untuk menghibur para pengungsi bencana Tsunami. Guest Stars for HUT Kota Banda Aceh pada tahun 2010 dan 2011. Ketika itu Inverno di undang untuk memeriahkan HUT kota Banda Aceh. Inverno juga pernah manggung di acara Harley Davidsontour Indonesia pada tahun 2012. Komunitas Harley David son di Aceh kemudian Inverno di Undang. Malam penutupan Polish Exspo, Blang Padang pada tahun 2017.31 Inverno di undang untuk tampil diacara closingPolish Exspo.

Karya-karya grup band Inverno sebagai dasar materi album mereka dapat dibagi kepada beberapa jenis. Pertama, religi. Hal ini dikarenakan makna dari lirik karya tersebut memuja tentang kekuasaan Allah SWT. Karya Inverno yang berbau religi antara lain Untuk mu. Satu lagu tentang ungkapan cinta kita terhadap orang tua, terhadap Allah SWT. cinta untuk kekasi, cinta untuk saudara dan banyak hal. Lagu lainnya adalah One Day Before lagu ini bercerita tentang bagaimana kekuasaan Allah SWT. tidak ada manusia yang tau kapan dirinya akan dipanggil oleh Allah SWT. Hari ini mungkin manusia yang akan diambil nyawanya oleh Allah SWT. masih sehat dan tidak ada tanda-tanda apapun yang bisa menyebabkan dia bisa meninggal ke esokan harinya, namun Allah maha kuasa, kapanpun Allah akan ingin mengambil hambanya kembali tidak ada yang mampu menghentikannya.

Selanjutnya adalah lagu dengan judul Pernahkah. Lagu ini bercerita tentang seseorang anak manusia yang melakukan kesalahan namun tidak bisa membicarakannya pada orang lain yang pada akhirnya hanya kepada Allah SWT. ia menceritakan masalah yang tidak bisa ia ceritakan dengan orang lain dan mayoritas manusia pasti pernah merasa demikian.

Kedua, cinta. Hal ini karena liriknya berbicara tentang hubungan sepasang kekasih dan seorang play boy. Karya Inverno yang bertemakan cinta adalah Takkan. Lagu ini bertemakan cinta, hal ini dikarenakan tema cinta lebih mudah diterima. Bercerita tentang sepasang kekasih yang sudah

31 http://docslide.net/documents/profile-inverno-update.html, diakses pada 22 Juli 2017

124 | pardian saputra 
lama tidak saling bertatap muka. Yang dilakukan oleh laki-laki tersebut adalah tetap nunggu wanita yang dia cintai. Ternyata setelah bertemu kembali wanita yang dia cintai masih menyimpan dendam dengan laki-laki itu karna kesalahan yang pernah laki-laki itu perbuat. Walaupun demikian laki-laki ini masih saja menunggu dan tetap mencintai wanita tersebut.

Kemudian lagu lainnya yang bertemakan cinta adalah Cantik Tapi Bohong. Lagu ini bercerita tentang seorang play boy yang merayu wanita dengan mengatakan semua wanita itu cantik, meskipun sebenarnya kebalikan dari pada itu. Dia terus mengatakan wanita itu cantik padahal tidak cantik.

Ketiga moral. Hal ini karna liriknya menggambarkan tentang bagaimana cara hidup yang baik, dan mempunyai sikap rendah hati seperti karyanya yang berjudul Hanya Satu Kali. Lagu ini memberi pesan bahwa sebetulnya kesempatan untuk hidup hanya satu kali. Hiduplah dengan cara yang baik, buatlah segala hal-hal yang positif, berikan yang terbaik dan jauhi yang negative. Judul lagu selanjutnya yang bertemakan moral adalah Ngaku RockStar. Merupakan lagu Rock and Roll, lagu ini bercerita tentang bagaimana seharusnya manusia menjadi sifat perendah hati. Seperti kata pepatah pakailah ilmu padi yang semakin berisi maka semakin tunduk. Filosofinya adalah ketika kita mempunyai ilmu maka kita harus semakin merendah.

Empat sosial, karna makna liriknya cara kita beradaptasi dengan lingkungan. Karya Inverno yang bertemakan sosial antara lain Tentang Kebebasan, lagu ini menceritakan tentang kebebasan yang dimiliki oleh setiap individu. Apa yang diinginkan kejarlah yang kita mau, terus perjuangkan apa yang dicita-citakan yang penting positif, tidak mengganggu orang lain dan tidak melenceng dari Agama. Judul lagu selanjutnya yang membahas tentang sosial adalah Dua Versi.32 Lagu ini bercerita tentang penghianatan yang dilakukan manusia terhadap manusia lainnya.33

\footnotetext{
32 Album Inverno dapat didownload secara free di https://www.reverbnation.com/inverno1.

33 Wawancara dengan personil Inverno Tebonk pada 24 juli 2017.
} 
Album diatas berjudul Tis Winter, Ain't A Hell, berkonsep Hard Rock/Glam Rock, dan mendapat pengaruh dari beberapa band antara lain seperti Guns N' Roses, grup band cadas ini menganut aliran Hard Rock. Grup band asal Los Angeles ini dibentuk pada tahun, 1985.34 Kemudian, Skid Row. Grup band yang dibentuk pada tahun 1986 ini bergenre Hard Rock. Grup band ini dibentuk di Amerika.35 Grup band lain yang memberi pengaruh pada warna musik Inverno adalah AC/DC, merupakan grup band asal Australia yang dibentuk pada tahun 1973. Grup ini setia dengan genre Rock.36

Dua grup band tersebut yaitu Cronic dan Inverno bergenre cadas. Mampu bertahan di Aceh hingga dewasa ini merupakan hal yang luar biasa. Grup band dengan genre Thrash Metal memang seharusnya susah untuk bisa manggung dan terkenal di Aceh. Namun hingga hari ini Cronic masih tetap eksis di daerah Aceh. Hal ini di karenakan konsistensi dari seorang personil Cronic. Tetap melangkah pasti kedepan dengan optimis sampai Cronic dapat diakui keberadaannya dan karya-karyanya diakui oleh penikmat musik di daerah Aceh dan luar Aceh.

Ada beberapa hal yang membantu grup band Cronic tetap eksis di daerah Aceh. Pertama, konsisten dalam berkarya.Konsistensi personil Cronic yang terus mencoba untuk bangkit disetiap halangan dan rintangan yang mereka hadapi. Dari sudut pandang materi yang dihasilkan dari karya-karya Thrash Metal sebenarnya hampir tidak bisa membantu perekonomian personil dan member Cronic sama sekali. Namun karna mereka merasa nyaman dan merasa tidak ada beban sama sekali ketika bermain musik tersebut dengan kata lain bermain musik dengan genre yang seperti itu memiliki kenikmatan tersendiri bagi mereka. Karna setiap orang memiliki hak untuk berekspresi namun tetap berjalan pada jalan yang baik dan tidak merugikan orang orang lain. Hal ini tergambar dalam sebuah status pada halaman facebook @cronicthrash yang dipost pada 2 juli 11:06 yang berbunyi "Berdiri di Aceh mempunyai suatu perjuangan mental yang kuat, caci, makian disingkirkan difitnahkan didukung oleh para sahabat yang setia,

34 https://www.facebook.com/gunsnroses, diakses pada 22 Juli 2017.

35 https://www.facebook.com/OfficialSkidRow, diakses pada 22 Juli 2017.

36 https://www.facebook.com/acdc, diakses pada 22 Juli 2017. 
bukan mudah untuk bisa tersenyum hari ini". Hal ini menjadi bukti bisu tentang perjuangan Cronic di Aceh.

Kedua, support dari berbagai pihak. Suport dari berbagai jenis media seperti MenZ burger, Foolshit Crew, Mask Production, Sendu Blogzine, Aceh Punk Scene, Bireun Underground Community, Bek Pungoe Scene, EST EM, Payong Seuni, Simphinic Blackness, Bathuphat Nosh Hard Crew, Bek Peungo Movement, Perpustakaan Jalanan Bandung, Keuneubah Indatue Merch, Bek Peungoe Zine, Bubblebloods Movement, Komunitas Anti Rokok Aceh, Mockingbird Japan Clan (LSM), OZ102 8FM Banda Aceh, Aceh Cloting Familia, Love Aceh, Hourglass Home Symphonic Blackness, Alchemist Music Fest, Bukan Dari Ibu Kota Movement, Honda Klasik Atjeh, Studio Tujuh Tujuh, GMA (gabungan musisi Aceh), yang selalu tidak bosan untuk menyediakan ruang untuk band-band dengan genre Thrash Metal menyampaikan suara mereka dan menyuarakan karya-karya mereka dengan menarik kepada penikmat musik tanah air.37 Kehadiran media sangat berpengaruh besar bagi eksistensi sebuah grup band di karenakan media merupakan salah satu alat penyampai pesan, dengan kata lain media merupakan salah satu cara berkomunikasi dengan individu maupun masyarakat yang menjadi sasaran komunikan. Karena komunikasi merupakan proses dimana individu dalam hubungan dengan orang lain, kelompok, organisasi, atau masyarakat merespon serta menciptakan pesan untuk berhubungan dengan orang lain dan lingkungan sekitar.38 Cronic juga memperkenalkan karya-karya mereka melalui facebook,39 instagram,40 dan web41 grup band Cronic.

Ketiga, undangan untuk tampil. Cronic juga eksis melalui tawaran untuk tampil di beberapa acara. Pada 23 mei 2014 Cronic diundang untuk tampil di acara Suara Bising I di Banda Aceh. Pada 10 april 2016 Cronic diundang tampil di acara HONDA TUHA ATJEH FESTIVAL dan lain-lain.42

37 https://www.facebook.com/pg/CRONICThrash, pada 25 Juli 2017.

38 Muhammad Mufid, Komunikasi \& Reguler Penyiaran (Jakarta: Kencana, 2005). hal. 3.

39 https://www.facebook.com/cronicthrush.

40 Instagram.com/cronicofficial

41 https://www.reverbnation.com/cronicthrash.

42 https://www.facebook.com/cronicthrush, diakses pada 31 Juli 2017. 
Adaptasi yang dilakukan oleh grub band Cronic di antaranya adalah dengan penyesuaian lirik yang kebanyakan mengangkat tema sosial, dan kekuasaan Allah SWT. melalui musik Thrash Metal di lagunya yang berjudul kota mati Cronic berbicara tentang kekuasaan Allah SWT dari kejadian Tsunami yang melanda Aceh pada tahun 2004.

Izin manggung yang susah untuk didapatkan ketika ingin mengelar konser dengan genre cadas mengharuskan mereka membuat acara mereka in dor dan Studio Tujuh Tujuh juga ada digunakan untuk acara musik mereka seperti acara yang bertemakan Suara Hati yang dilaksanakan di studio tersebut.

Cronic sendiri bertahan di karenakan ada rasa kenyamanan tersendiri bagi mereka ketika mereka bermain musik dengan genre tersebut. Berlandaskan pada rasa nyaman dan suka terhadap genre Thrash Metal membuat mereka bisa bertahan hingga hari ini di Banda Aceh.

Kemudian, karena musik Thrash Metal banyak mengambil tema sosial dalam pembuatan karya-karya mereka membuat musik dengan genre cadas itupun secara perlahan mulai disukai oleh peminat musik.

Pakaian yang digunakan juga tidak seperti pakaian yang digunakan oleh mayoritas grup band genre Thrash Metal pada umumnya. Cronic lebih terkesan biasa saja dalam hal tersebut. Setiap kali mereka tampil, mereka mengenakan pakaian yang sopan.

Inverno juga memperkenalkan musik dan karya-karya mereka melalui event-event musik dan festival sama halnya seperti Cronic. Inverno juga eksis melalui support media.

Sama halnya seperti grup band Cronic, inverno juga mencoba untuk eksis melalui event-event yang ada di Banda Aceh dan luar daerah Banda Aceh. Pada 19 april 2019 Inverno diundang tampil di acara Guest Star HUT Banda Aceh Musik Festival dan Polish Expo pada tahun 2017 di Blang Padang.

Inverno juga mendapat respon yang baik dari para penggemarnya melalui album mereka. Sekarang Inverno sudah merilis satu album sebagai 
pondasi awal musik mereka. Selain itu grup band Rock ini juga memiliki akun facebook, 43 instagram, 44 twitter, 45 youtube. 46

Adaptasi yang dilakukan Inverno juga terlihat melalui penyesuaian musik yang mereka bawakan. Seperti halnya konsep yang digunakan dalam album Inverno yaitu konsep manis tapi keras. Maksudnya adalah Inverno ingin tetap konsisten dengan genre Rock akan tetapi bisa memanjakan telinga penggemarnya dengan musik yang enak dan nyaman untuk didengar.

Kemudian dari ke Sembilan karya inverno banyak bercerita tentang kekuasaan Allah dan Cinta. Inverno memilih tema cinta di dalam setiap lirik lagu merka karna tema cinta lebih mudah untuk diterima oleh banyak penikmat musik sebab sasaran Inverno adalah remaja. Hal ini dapat dilihat pada setiap lirik lagu Inverno yang selalu berisi pesan moral yang positif seperti lagunya yang berjudul "Hidup Hanya Satu Kali”.

Dari segi kemasan ketika mereka konser, mereka selalu menyesuaikan dengan tema acara tersebut, baik itu dari segi nyanyi yang dipilih juga fasion dimana tempat mereka tampil untuk mengisi acara ataupun konser.

Berdasarkan dengan isi dari fatwa MPU (Majelis Permusyawaratan Ulama) Nomor 12 tahun 2013 tentang Seni Budaya dan Hiburan lainnya dalam Syariat Islam seharusnya semua jenis musik yang menggunakan alatalat seperti gitar, piano, bass, biola, dan seruling, kemudian harus memenuhi keriteria busana muslim dan muslimah, syair dan nyanyian tidak mengandung fitnah, dusta, caci maki dan yang dapat membangkitkan nafsu syahwat dan lainnya tidak bisa berkembang di Aceh.

Namun pada realitanya fatwa MPU pada tahun 2013 tersebut tidak terealisasikan degan baik dalam masyarakat sejauh ini. Faktanya sangat banyak radio-radio bisa memutar musik genre apapun yang mereka suka, masyarakat bisa mendegar musik apapun yang mereka suka karna mereka juga dilindungi ole hukum negara. Tidak tertutup kemungkinan bahwa grup band cadas ini akan mampu untuk terus eksis dan beradaptasi di Aceh di

43 Official facebook inverno dapat diakses di https://www.reverbnation.com/inverno1.

44 Instagram.com/inverno_official

45 Twitter.com/inVerno_ID

46 Official youtube inverno dapat diakses di https://www.reverbnation.com/inverno1. 
karenakan banyak hal, diantaranya adalah karna kekuatan dan konsistensi para anggota grup band tersebut sangat kuat.

Penyesuaian lirik dan musik yang dibawakan oleh grup band Inverno membuat mereka lebih mudah untuk diterima oleh penikmat musik di Aceh. Hal ini dibuktikan dengan diundangnya mereka ke acara HUT kota Banda Aceh pada tahun 2010-2011 dan Polish Expo pada tahun 2017. Hal ini berbeda dengan apa yang dialami grup band Cronic. Grup band Cronic memiliki tantangan yang lebih berat terkait dengan eksistensi mereka. Hal tersebut kemudian mengharuskan mereka membuat acara mereka in dor. Meskipun demikian Cronic juga pernah diundang tampil di acara Out dor.

\section{PENUTUP}

Adapun kesimpulan yang dapat diambil dari hasil penelitian mengenai perkembangan, eksistensi, adaptasi grup band Inverno dan Cronic yang dilakukan di Banda Ac eh adalah: Grup band Inverno dibentuk pada tahun 2011 dan Cronic di bentuk pada tahun 1999. Dalam perkembangannya ke dua grup band tersebut mengalami banyak tantangan namun masih tetap eksis hingga dewasa ini.

Grup band Cronic dan Inverno eksis melalui konsistensi para personilnya dalam dalam berkarya dan support dari berbagai pihak diantaranya seperti Gabungan Musisi Aceh (GMA), OZ102 8FM, Komunitas Anti Rokok Aceh dan lain-lain. Tidak seperti grup band dengan genre Thrash Metal dan Rock idealnya, Cronic dan Inverno menjunjung tinggi, menghormati, dan menyesuaikan diri dengan setuasi dan kondisi sosial di Aceh. Grup band cadas ini menyesuaikan diri melalui makna lirik dari setiap karya mereka, penyesuaian pakaian yang mereka gunakan ketika mereka konser, dan pemilihan tema dari setiap album dan single yang mereka keluarkan. Dengan penyesuaian dan adabtasi ini maka group band ini tetap eksis dan dapat berkarya dalam konteks penerapan Syariat Islam di Aceh. 


\section{DAFTAR PUSTAKA}

Emzir, 2011, Metode Penelitian Pendidikan Kuantitatif dan Kualitatif, (Jakarta: PT. Raja Grafindo Persada.

Fatwa Majelis Permusyawaratan Ulama Aceh Nomor 12 Tahun 2013.

Misran, 2012. "Pelaksanaan Syari'at Islam di Aceh", Legitimasi, Vol. 1, No. 2, Januari-Juni.

Mufid, Muhammad, 2005. Komunikasi \& Reguler Penyiaran, Jakarta: Kencana.

Soedarsono, R.M., 1992. Pengantar Apresiasi Seni, Jakarta: Balai Pustaka.

Uki, Whiwdon Jagad, "Bedanya Musik Metal Dan Musik Rock", Sinar Harapan, 30 Juli 2015.

Nugroho, Wahyu, "Sepultura Seharusnya Sudah Tamat", SINDONEWS.COM, 2015.

\section{Media online}

http://2013.hammersonic.com/line-up/sucker-head.

http://docslide.net/documents/profile-inverno-update.html.

http://musik.or.id/profile-inverno.

http://www.izaybiografi.com/2016/01/biografi-pas-band.html.

http://www.rhybuckrecords.com/2014/09/cronic-biography.html.

https://akatsuci.wordpress.com/sejarah-within-temptation.

https://gendown666.wordpress.com. 
Aceh Anthropological Journal Volume 2 No. 2 Edisi oktober 2018

https://kandidatmusisi.wordpress.com/sejarah-perkembangan-iron maiden.

https://klinikmusik.wordpress.com/2014/10/19/genre-musik/.

https://www.facebook.com/acdc.

https://www.facebook.com/cronicthrash.

https://www.facebook.com/cronicthrush.

https://www.facebook.com/cronicthrush.

https://www.facebook.com/DyingFetus/.

https://www.facebook.com/gunsnroses.

https://www.facebook.com/KreatorOfficial.

https://www.facebook.com/OfficialMotorhead.

https://www.facebook.com/officialnapalmdeath.

https://www.facebook.com/OfficialSkidRow.

https://www.facebook.com/pg/CRONICThrash.

https://www.metal-archives.com/bands/Slayer/72.

https://www.reverbnation.com/cronicthrash.

https://www.reverbnation.com/inverno1.

Instagram.com/cronicofficial.

instagram.com/inverno_official.

132 | pardian saputra 
https://www.reverbnation.com/inverno1

https://www.reverbnation.com/inverno1.

twitter.com/inVerno_ID.

\section{Informan}

Tebonk.

Adi Cronic

Adi Kriting.

Alif Maulana

Teuku Furqan 